像燈塔一樣已給全國人民指出了努力的方向, 給 科學工作者指出了廣濶的發展遠景。我們科學工 作者必須緊密地㖥結在毛主席和共産黨的周圍,
與廣大人民在一起，共同努力前進。㯰樣我們就 一定可以完成我們莊筑的任䅂，不辜負我們新中 國的科學工作者這一光榮稱栫。

\title{
參加世界醫學會議記 要
}

\author{
薛墨 \\ (北京 㗨 学
}

第二次世界大戰以後, 各國人民由於戰爭的 影響，以及以美國帝國主義篇首的侵略陣營積極 借戰演軍的結果, 許多國家人民的生活水平日益 降低，健康條件愈形惡化。新戰爭的威叠還繼續 存在着。世界各國的醫學工作者重視逜一事實， 更認識到器展人民衛生事業, 保障人類健康是醫 務工作者責無产袋的天職。因此，决定召開一個 世界性的登學會議桃討論和研究這些問題。大會 原定於 1951 年 9 月在意大利的首都羅馬召開, 由 於受到意大利反動政府的阻止，因而不能如期舉

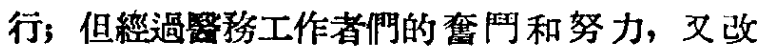
定於 1952 年 10 月在意大利北部温泉召開, 結果 又同樣地遭到意大利反動政府的阻撓。但是這種 阻撓並没有使醫務工作者們灰心，反而增加了大 家的闰志和决心，結乐，迋個大會終 於 在 1953 年 5 月 23-25 日在奥地利首都維也納順利地舉行 了.

出席這次會議的代表共有 200 餘人，來自 30 多個不同的國家，我國也派遗了由 16 人組成的代 表團出席了這次會議。不少國際上著名的學者， 如蘇聯保健部學術委員會主席柯契金、捷克斯洛 伐克科學院院士馬立克、保加利亞科學院院長波 波夫、英國劍橋大學㕵會系系主任司徒德、法國

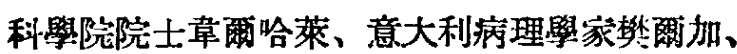
最近獲得斯大林和平獎金的印度細菌學專家索克 等都參加了會議。會議一直是在友好熱烈的氣氛 中進行的。大會宣讀了 70 餘篇科學與專題報告, 報告了各國人民的生活和衛生情况，无其對於戰 争如何成篇推殘人類的主要因素, 作了詳細的說 明。我國代表團團長方石㬂同志也在大會的第二 天作了“戰争對於人類健康的影響”的專題報告。
我們報告的內容，主要說明我國在解放以前 反動政府統治下人是健康的瑟少情况，但作中國 人民解放之後，短短三年中，衛生工作獲得诋速 的進展, 這一具體而生動地說明了新中國衛生建 設事業成就的報告, 得到其他各國代表熱烈的歡 迎, 很多國家代表都向我國代表團團長歡呼，全 體代表一致要求我們分送報告的譯文。我們的報 告大大地鼓舞了殖民地、牛殖民地國家的代裴 們，如有一位印度代表說: “我希望中國第一個五 年建設計劃成功。它將給印度 36,500 萬人民以更 大的鼓舞，我們一定要走中國的路。”同時，我 們的報告也約正了資本主義國家的葉些代表過去 在反動統治者的歪曲宣傳影響之下産生的對新中 國的錯誤認識, 如一位西德的代表說“要不是親 自與中國代表談話, 真不知道新中國進步的真筫 情况。”代表們一致讚揚和擁護我們的報告，在聯 歡會上有許多國家的代表用他們那種剛洞學會而 不熟練的中國話歡呼: “毛澤束! 乾杯!”我們深 深地感到了在毛主席和中國共漟黨的英明領導下 獲得解放的中國人民的光榮興酥儌。

大會上各國代表的報告，也正是䇃會主義制 度和資本主義制度的一個强烈的對比。

在資本主義國家裏，人的健康日䖯琹化， 如結核病、營養缺乏症、精神病等都亚遍的坦 加了。英國的結核病患者 1949 年就比 1948 年堆 加了 64\%; 意大利因患結核病死亡的工人佔其總 死亡數的 $24 \%$; 患營秦缺乏病者在意大利和奥地 利都很筇重，例如，意大利南部是歐洲出产橾子 的地區，但南意大利人民患缺泛䊒生素丙的滾血 病者特別多，奥地利人民患營養缺乏病者澾 $32 \%$ ，一般焒食不足者澾 $71 \%$; 英國人民的營春 
也同樣缺乏。精神病在資本主義國家最第嚴重, 如 在美國醫院中的任院病人大多数是精神病患者, 可是還有 200 萬精神病人不能入院，據梳計美國 有 1000 萬人需要精神病治療，每個精神病 科 生, 要照顧 450-600 個精神病人。據美 國 1948 年出版的“美國之耻”一書中說: “美國精种病院最 人道的治療方法, 就是給病人穿上緊身衣服, 用帶 子佣起來，用鍕子鎖在踤上，每一個病室都有鞭 子, 作篇治療和致育的武器。”在法國巴悡每天至 少有一人因精神失常而自殺; 在希臘兒童作夢的 內容, 有 $60 \%$ 是戰爭恐怖。以上種種光分說明了資 本主義國家人民健康的惡劣情况與死亡的威脅。

在殖民地和牛殖民地國家裹, 人民受着疾病 和死亡的噘重威叠，例如，阿爾及利亞兒童死亡 率竟澾 76\%；婦女因營食不良而引起的骨盤畸形 達 $1 \%$, 産婦死亡率澾 $36 \%$; 性病在伊朗也很普遍。 伊期人民營䖭不足，每日食物的熱量僅 有 1,200 卡(正常情况每日每人需要熱量 3,000 卡左右)， 因此侏朗人民患貧血症非常普遍。由此可見殖民 地、牛殖民地國家的人民在帝國主義的殘酷鉸削 和厩迫下，其健康情况日益惡化。

與此相反的，是蘇聯及人民民主國家人民衛 生保健事業逢勃的發展。在蕉聯早已完全消隇了

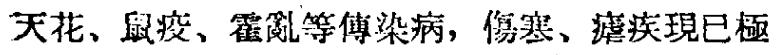

第少見，結核病日谷減少，性病已成了歴史与的 名詞。蘇聯人口三年來增加了 950 萬。蘇聯革命 成功初期, 平均每 30,000 人才有一個醫生, 現在 平均 895 人就有一個醫生, 有些地區每 400 人就 有一個醫生。勞動人民每年有 5 個星期的休䓹假 期, 婦女産假是 77-91 天。䓠聯在醫 療機構方 面，現有醫樂學院 100 個，專科研究所 347 所， 醫生 30 多萬人，研究人員 2 萬多人。人民民主國 家的捷克斯洛伐克，自人民掌握政權以來，人口 出生率增加了 $39 \%$, 嬰兒死亡率減少了 $3 / 4$, 結核 病的死亡率也減少了 $48 \%$ 。目前每 800 人有一 個醫生，全部人口的 $90 \%$ 得到了免費醫療，每 1,000 個人有 10 張病休。捷克斯洛伐克現有 7 㑬 醫學院，2 個藥學院，21 個醫樂衛生研究所。波 蘭的結核病死亡率也降低了 $49 \%$ ，而且患者都能 獲得免費醫療。由於蘇聯及人民民主國家致力於 和平建設，人民衛生保健事業就獲得了空前迅速 的發展。

根據這些活生生的事賸的對比，圣體代表都 篇蘇聯與各人民民主國家的人民健康事業的發㕈 而歡呼，而對資本主義國家人民的健康狀况表示 射夏，對帝國主義奴役下的殖民地與牛殖民地人 民的健康情况的惡化表示同情與慎亚。大家一致 表示了爭取和平、保障人類健康與幸福的愿望。 